\title{
Post-Consumer plastic packaging waste management in Indonesia: a producer responsibility approach
}

\author{
Siti Kardian Pramiati ${ }^{*}$, Tri Edhi Budhi Soesilo ${ }^{1}$, and Haruki Agustina ${ }^{1}$ \\ ${ }^{1}$ School of Environmental Sciences, Universitas Indonesia, Central Jakarta 10430, Indonesia
}

\begin{abstract}
In a country with a large and diverse population such as Indonesia, the waste problem is difficult to solve, especially in urban areas. The growth of the population in urban areas has been accompanied by their rapid development of infrastructure and industrial growth. The dynamic lifestyle of urban communities changes their consumption behavior to products that are more practical in packaging. There are fundamental things that arise in the waste management system in Indonesia, including limited waste management capacity in the regions, inadequate infrastructure, implementation of regulations, and a lack of public concern, including the manufacturing industry, on waste management issues. Through the approach of the concept of extended producer responsibility (EPR). However, EPR concept implementation in developing countries is still lacking, where the collection and recycling system has not been adequately addressed. On the other hand, the industrial sector does not yet have enough attention to expand its product responsibilities for the post-consumption stage. This article presents an overview of current practices of post-consumer packaging waste management through an extended producer responsibility mechanism in Indonesia. More specifically, this study focused on consumer goods manufacturing industries. Based on the literature study, various industrial efforts have been shown to adopt the EPR concept in handling its product packaging waste.
\end{abstract}

\section{Introduction}

Solid waste management has become a major concern for many urban managers around the world, including in Indonesia, a country with a high population density. Solid waste management in Indonesia is primarily caused by the high volume of waste products, the limited capacity of final disposal sites, waste management technology cost, and lack of public awareness that can bring new problems such as water pollution and flood disaster.

Based on the 2018 Environmental Indifference Index, the most indifference of Indonesians to the environment is in the dimension of waste management, compared to indifference to the energy management, water-saving, or public transportation dimensions. The high level of indifference to waste management is shown by the behavior of households in Indonesia in terms of waste handling. More than half of households in Indonesia use environmentally unfriendly methods when managing waste. The survey results show that as many as $53 \%$ of respondents burn trash, 5\% throw garbage into rivers and $2.7 \%$ throw garbage everywhere. Public ignorance is also reflected in behavior towards plastic waste, as many as $81.4 \%$ of people do not care about plastic waste [11].

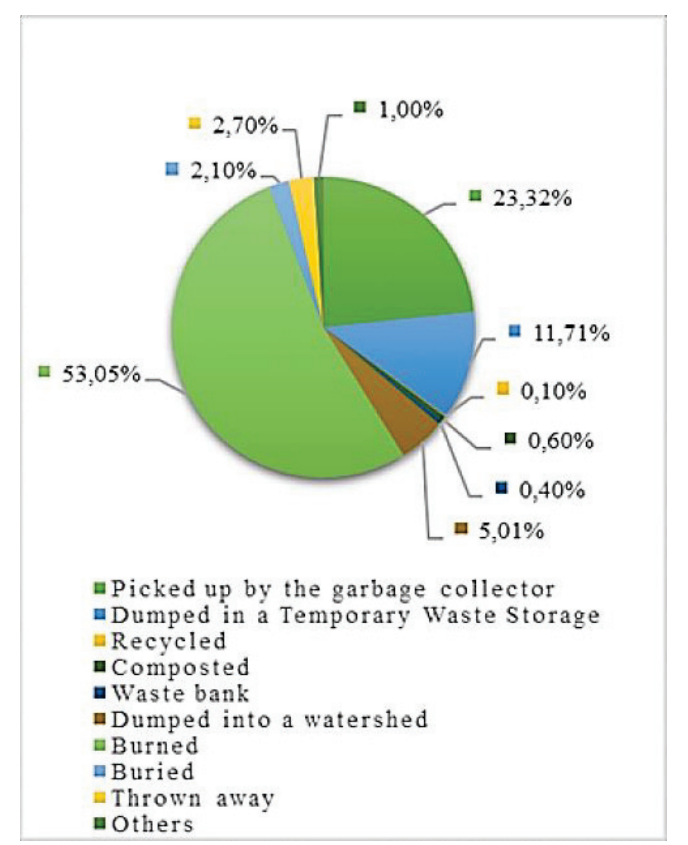

Fig 1. Percentage of Indonesian households based on frequent waste handling (Central Bureau for Statistics, 2018)

Only about $60 \%$ of waste in big cities in Indonesia can be transported to final processing sites (TPA), whose

\footnotetext{
* Corresponding author: dhiankui@gmail.com
} 
main operation is landfilling. The landfilling system is the mainstay of a city in solving its waste problem [11]. According to the National Waste Management Information System Data (2018), the amount of waste in DKI Jakarta that is dumped in the TPA reaches 11 thousand tons per day and 273 tons is still not manageable. Changes in the lifestyle of urban communities, including changes in consumption patterns, can affect the generation of waste generated every day, including plastic packaging waste. The generation of plastic waste reaches $16.69 \%$ of the composition of Indonesia's national waste [11], even the DKI Jakarta Provincial Environmental Agency stated that DKI Jakarta produces 357 tons of plastic waste every year.

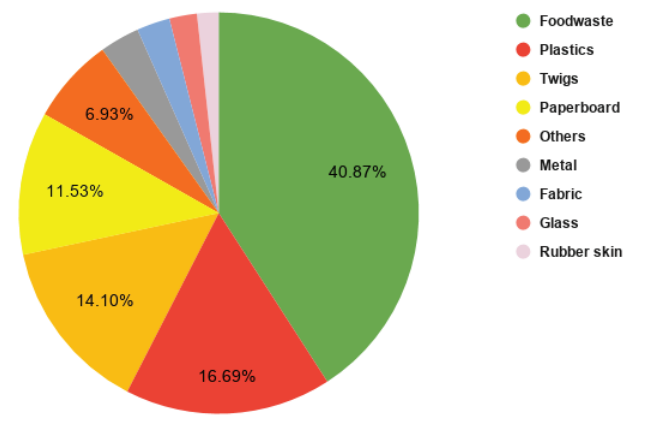

Fig.2. Solid waste compotition by type (MoEF,2020)

Almost all food packaging and goods use plastic and plastic bags. The use of plastics has been discovered in the 20th century. And growing tremendously from just a few hundred tonnes/year in the 1930s, to 150 million tonnes/year in the $1990 \mathrm{~s}$ and 220 million tonnes/year in 2005. Plastic production on an industrial scale began in the 1940 s, then estimated to grow at an average of 10 percent per year. The increase in global production occurred from 1.3 million tonnes in 1995 to around 300 million tonnes in 2014 [17].

A total of 400 million tons of plastic are produced worldwide every year for various purposes, including as a wrapping material because it is lightweight and functional. About 150 million tons of plastic waste are in world waters. Its growth is no less great, reaching 8 million tons per year [13]. Plastics have become popular in the industrial sector because of their special characteristics, flexibility to shape according to needs; lightweight and easy to transport; durability; safe from chemical contamination and its impacts; sealability; weather and temperature resistance; and more importantly, it is cheap.

The use of plastic materials in Western European countries reaches $60 \mathrm{~kg} /$ person/ year, in the United States, it reaches $80 \mathrm{~kg} /$ person/year, while in India only $2 \mathrm{~kg} /$ person/year. Indonesia has stated as the second largest country contributed to plastic pollution in a marine environment, reaching 187.2 million tons after China, which reached 262.9 million tons. Meanwhile, in third place was the Philippines, which contributed almost 83.4 million tonnes of plastic waste, followed by Vietnam with 55.9 million tonnes, and Sri Lanka with 14.6 million tonnes per year [11]. This phenomenon can occur because every year the Indonesian sea is estimated to receive $70-80$ percent of plastic waste sent from land which is used for human consumption. The amount is between 480 thousand and 1.29 million tons of plastic waste from a total of 3.22 million tons of garbage that enters marine and coastal areas [13]. Plastic pollution in Indonesia is predicted to increase in line with the development of the consumer goods industries in Indonesia, considering that this is one of the fastestgrowing sectors. In the first quarter of 2019, the growth of the beverage processing industry reached $24.2 \%$ on an annual basis. Some materials are considered to have the same characteristics as plastic. Quite a lot of ingredients have better quality if compared to plastic. Unfortunately, this material is more expensive than plastic so that industry is reluctant to replace raw materials because it will increase production costs and reduce profit margins [5].

\section{Material and method}

A systematic literature review was carried out to record how packaging plastic waste management schemes were organized in Indonesia, as well as their main results. The scientific literature on plastic waste is extensive and most of them describe plastic management technology; however, no comprehensive review was carried out to assess the role of producer responsibility in managing their packaging waste, which was the main focus of this article. This article also covered gray literature and some case studies of producer initiatives in several consumer goods industries. Data presented in this article came from previous researches that could be more updated in the next researches data with the same keyword focuses.

\section{Result and discussion}

Since 2005 the Government of Indonesia has shown concern for environmental problems, particularly waste management, following the issuance of Law Number 18 of 2008 regarding Solid Waste Management. The main mandate of waste management in this law is to change the paradigm of waste management from collecttransport-waste to reduce at source and recycle resources. To replace the end of pipe approach, the government implemented the $3 \mathrm{R}$ principle approach (reduce, reuse, recycle), extended producer responsibility (EPR), processing and utilizing waste into resources, both as raw material and a source of renewable energy,

The policy on EPR has been mandated in Law Number 18 of 2008 regarding Solid Waste Management, particularly in Article 1 which reads: "Producers are required to manage packaging and/or the goods they produce which cannot or are difficult to decompose by natural processes". Although this article does not textually mention EPR, the presence of this law is a legal basis for demanding the roles and responsibilities of producers in efforts to reduce and handle waste because producers, through the products and packaging of the products they produce, are one of the sources of producing waste. 
In general, EPR is described as a pollution prevention policy that focuses on the production system rather than the production facility. Thus the responsibility for products extends beyond the emissions and wastes generated by extraction or manufacturing processes to include product management of the product after disposal. The concept of EPR or sustainable producer responsibility is the principle of environmental protection policies to reduce the environmental impact that comes from the product life cycle by extending the responsibility of the manufacturer for the product life cycle by recalling and final disposal of the product after the sale [11][11].

To meet the needs of dynamic urban communities, the consumer goods industry sector is growing rapidly producing goods with practical and economical packaging. Most consumer goods manufacturers choose plastic to package their products. This plastic packaging has become a big problem for the environment in Indonesia. The characteristics of plastic are made durable, flexible, lightweight and price, sealable, puncture and water resist [9][17]. Several types of packaging waste cannot be recycled. With such characteristics, packaging waste becomes a multidimensional problem. This is important to resolve and find solutions together, not only from the government. It takes a strong commitment from various parties to collaborate to solve these problems, including the commitment of the manufacturing industry as a producer.

The Ministry of Environment and Forestry of the Republic of Indonesia designs targets for producers to reduce 30 percent of waste from products and/or product packaging by 2029 . The target of reducing plastic packaging waste in Indonesia has become part of the Roadmap for Reducing Plastic Waste by Producers [17]. Several commitments to reduce plastic waste have been demonstrated by the consumer goods manufacturing industry in Indonesia, in various ways.

\subsection{Take-back Post-Consumer Packaging Waste}

Some popular brand owner entities have taken initiatives to run a take-back program. A collaboration between several consumer goods manufacturing industries has been carried out to help reduce the amount of packaging waste through the Dropbox Packaging Trash program. This collaborative action begins with the placement of five Packaging Waste Dropbox in a number of supermarket outlets in the Jakarta, Bogor, Depok, Tangerang and Bekasi areas. The type of waste collected at Dropbox is valuable inorganic waste which consists of three categories, namely the paper packaging waste category, the plastic packaging waste category, and the glass packaging waste category. All of the collected waste will be transported by the pick-up partner, namely the Waste Bank, to then be channeled and processed by recycling centers into goods that are more useful and have economic value. Multinational bottled beverage product companies have shown their commitment by collecting post-consumer packaging and trying to recycle them equivalently to the number of packages sold. This program established a partnership with informal sectors to help collecting packaging waste [11]. In fact, the informal sector plays an important role in Indonesia's recycling sector [9][5].

\subsection{Redesign the packaging}

In addition to the take-back packaging waste program, some entities initiate redesigning of packaging into sustainable packaging. A multinational bottled water company targets 100 percent of its packaging to be recycled by 2025 [17]..The results of this innovative plastic waste recycled packaging are claimed to be safe for consumption. The packaging has met the standards set by BPOM, Halal, SNI and FSSC 22000.Thus, the quality of the recycled packaging is the same as bottles virgin PET or new PET, so the bottled water products are of the same quality.

\subsection{Develop package free shopping services}

As a form of commitment to reduce plastic waste, a fast moving consumer goods company presents a refill station as an example of applying the circular economy concept. This concept emphasizes the importance of elements of reuse and recycling, and reduces the use of plastics. The concept then developed into a consumer goods store without packaging that accustoms consumers to shopping with their own containers. This method is quite effective and efficient to reduce the use of plastic packaging for daily necessities, while still paying attention to safety and quality control from the factory.

\subsection{Build recycling facilities}

A food company giant association shows its commitment by building a waste management technology infrastructure for an investment of 90 million US dollars to improve waste management and technology. Some brand owners had conducted voluntary business and non-business activities to reduce the impact of their product packaging and improve the capabilities of the existing recycling sector. The challenge faced by the existing initiatives is the poor quality of the collected materials. The quantity collected is also small and the scale of the activity is limited. Consumer lifestyle can also contribute to the quality of the materials. Another challenge mentioned in the previous research was the high transportation costs associated with the take-back program considering the geographical challenges [11].

\section{Conclusion}

The industry contributions in implementing sustainable systems in consumer lifestyle can also contribute to the quality of the materials. The high transportation costs associated with the take-back program considering the geographical challenges packaging plastic waste management plays an important role in plastic waste management in Indonesia. The target of reducing plastic 
waste can be achieved if industrial sector as producers continue to innovate and educate consumers to adopt an eco-lifestyle in using plastic and manage household waste. Producers in Indonesia need to work together with related stakeholders to implement a sustainable system to help reducing the amount of packaging plastic waste in Indonesia effectively. Each producer may consider different systems in handling the plastic packaging waste in post consumer level, however developing a collective awareness in managing plastic waste properly is the main idea of plastic waste management in Indonesia.

This article was supported by The Grant of Indexed International Publication for Post Graduate Studies (PUTI Q4) Universitas Indonesia 2020, with contract number: NKB2563/UN2.RST/HKP.05.00/2020.

\section{References}

1. A.P.N. Sulami, T. Murayama, S. Nishikizawa, Environment and Natural Resources Journal, 16(1), 70-81 (2018)

2. B. Raj, Plastics and Their Role in Food Packaging, Food Packaging Technology Department Central Food Technological Research Institute, 020, 17-46 (2018)

3. Central Bureau of Statistics, Laporan Indeks Perilaku Ketidakpedulian Lingkungan Hidup Indonesia 2018 (2018)

4. E. Damanhuri, T. Padmi, Pengelolaan Sampah. Program Studi Teknik Lingkungan ITB (2010)

5. F. Zahra., T. P. Damanhuri, Studi Teknik Lingkungan, Jurnal Teknik Lingkungan, 17(April), 59 (2011)

6. G. Hickle, Business Strategy and The Environment, 26(1) (2015)

7. I. Muise, M. Adams, R.Côté, \& G.W. Price, Conservation and Recycling, 109, 137-145 (2016)

8. J.R. Jambeck, Q. Ji, Y.G. Zhang, D. Liu, D.M. Grossnickle, Z.X.Luo, Science, 347(6223), 764768 (2015)

9. M. Chaerul, A.R. Fahruroji, A. R., \& T. Fujiwara, Journal of Material Cycles and Waste Management, 16(3), 509-518 (2014)

10. Ministry of Environment and Forestry Regulation No. P.75/MENLHK/SETJEN/KUM.1/10/2019, Ministry of Environment and Forestry (2019) https://doi.org/10.1017/CBO9781107415324.004

11. Ministry of Environment and Forestry, Sistem Informasi Sampah Nasional

12. Qonaah, Jurnal Komunikasi, 48-55 (2019)

13. T.Tasaki, N.Tojo, T. Lindhqvist, International Survey on Stakeholders 'Perception of the Concept of Extended Producer Responsibility and Product Stewardship (Issue May) (2015)

14. World Economic Forum, Mengurangi polusi plastik secara radikal di Indonesia: Rencana aksi multipemangku kepentingan. Laporan Mendalam, April, 47 (2020)

15. World Econonic Forum, White paper Circular Economy in Cities report 2018 (2018).

16. Y.A. Hidayat, S. Kiranamahsa, M.A. Zamal, AIMS Energy, 7(3), 350-370 (2019)

17. H. Metropolia, Zuzana Sedlacekova Food Packaging Materials Comparison of Materials Used for Packaging Purposes (2017) 